\title{
The Evolving Trend in Indian Poetry in English
}

\author{
Dr. Manjit Kaur
}

\begin{abstract}
Indian Poetry in English has evolved from spirituality to specificity as its major preoccupation and concern. If we look at pre independence poetry, we meet the stalwart figures of Tagore, Sri Aurobindo and the like who despite their deep patriotic concerns wrote poems evincing their focus on the matters of soul, God or ultimate truth. These poets were very close to the spirit and tradition of Vivekananda and Ram Tirtha who were in the thick of the India awakening in the renaissance period through forging an identity and unity not only within them but also between East and West cultures. The poetry of Sarojini Naidu and Tagore although drew heavily from the Indian scenes was suffused with romanticism to the extent of making it abstract to a large sense. During the post independence period, as a result of the decolonization or at least an attempt at it, Indian poetry wore a different and fresh face with the coming of Nissim Ezekiel, Ramanujan, Kamala Das to name a few on the scene. These poets ushered in a total radicalization on the issues of language and content. Giving up old traditional rhyme, gush of romantic similes, rhetoric and high sounding and sweeping imagery, the shift could be felt in the concretization of thoughts and feelings expressed in a concrete style. Specificity of location and theme on the basis of one's cultural and historical reality has made the poetry of present day generation more readable and relevant. The present paper attempts to analyse the above shift in the poems of the selected poets.
\end{abstract}

Keywords: Cultural, English, Indian, Poetry, Pre independence, Post independence, Reality, Spirituality, Specificity, Universality

\section{Introduction}

While travelling with time, Indian Poetry in English has moved from spirituality to specificity as its major preoccupation and concern. The present paper attempts to focus on the pre Independence poetry in the Indian Renaissance period starting from the spiritual nationalist concerns of Sri Aurobindo, idealist and romantic undertones of Rabindranath Tagore and Sarojini Naidu's poetry to the post independence poets such as Nissim Ezekiel, A.K. Ramanujan, Kamala Das and others with an endeavour to build the argument that the present foregrounding on the specificity of the cultural and social realities of the times has made the poetry more relevant and readable for the common readers.

\section{Pre Independence Poetry}

Indian poetry in English draws its tradition from the spirituality and the universality of human concerns. Spirituality and a deep faith in the basic assumptions of Hindu religious tradition resting on a long history of Vedas, Upanishads and our great epics was an answer to the challenge posed to Indian culture with the introduction of English language and western education in the early 19th century. In a bid to forge unity among Indians and boost up their confidence, the task of spiritual resuscitation and national construction was undertaken by the spiritual and religious leaders like Raja Rammohan Roy, Ishwar Chandra Vidyasagar, Dayanand Saraswati, Ramkrishan Paramhans, Swami Vivekanand and others. As K.R.Srinivasa Iyngar writes that all gods were brought under one transcendental Brahman i.e. one God, realisation of which was the social, emotional as well as the political necessity keeping in mind the confusion and the tension between eastern and western values in those times.[1]

Sri Aurobindo with his prolific contribution to Indian English poetry was the forerunner of the spiritual strings in the Indian verse. He is best known for his works The Life Divine, Savitri and a number of poems like "Rose of God", "The Golden Light", "God", "Life and Death", "Transformation" etc. According to Aurobindo, as is stated in his book The Future Poetry, poetry is a mantra, , showing a doorway to the spiritual life and that the music of the poem is born out of the kindled emotions and vision making the words highly suggestive and harmonious.He writes:

..., the whole style and rhythm of poetry are the expression and movement which come from us out of a certain spiritual excitement caused by a vision in the soul of which it is eager to deliver itself.[2]

Aurobindo further suggests that the deep and intuitive poetry has the capacity of transforming the consciousness of human beings and evolving them into supramental beings, the arrival of the stage of sacchida anand which implies infinite existence, infinite consciousness and infinite delight or bliss. In his long poem 
"Savitri" which is about 24000 lines,based on the story of Savitri and Satyavan occurring in Mahabharata, Savitri realises her divine self, achieves victory over death and returns to earth along with Satyvan to perform a spiritual mission of 'lifting earth beings to immortality.'

Tagore's Gitanjali almost conveys the same thoughts. Human body has been likened to a vessel emptied and filled by God at birth and death.

'Thou hast made me endless, such is thy pleasure. / This frail vessel thou emptiest again and again and fillest it ever with fresh life'.

And further writes:

'This is my prayer to thee my lord- strike strike at the root of penury in my heart'

God is the provider of an unending joy to know which, one has to lose oneself in the total joy of cosmic play.

'Thy infinite gifts come to me only on these small hands of mine. Ages pass, and still thou pourest. And still there is room to fill'.

To realise divinity, one has to occupy oneself in an honest labour. Tagore writes: 'Leave this chanting and singing and telling of beads' which is resonant of what Aurobindo says

He who would bring the heavens here

Must descend himself into clay.

Tagore's mysticism was closely linked to his humanistic values of love, compassion and sympathy for all fellow beings. In many of his poems, he warns the people against the unjust treatment meted out to the under privileged. Even Sarojini Naidu who is known for the melody and music in her poems, depicts the pictures of the marginalised classes of India such as weavers, fishermen, snake charmers, dancers, palanquin bearers with a remarkable delicacy and sympathy. But her treatment is romantic and diction mellifluous.

In "Palanquin Bearers", she writes:

Lightly o lightly we bear her along

She swings like a flower in the wind of our song.

The term spirituality also suggests the universality of human experience or the humanistic concerns of the poets which to a great extent fail to highlight the particularity of human life placed in the specific socio-cultural contexts. In this respect, Post Independence poetry in English seems to do justice to it through its presentation of the particularity of human experience in India as the country was coming to terms with the fresh phase of social political and economic reality.

\section{Post Independence Poetry}

It will not be an exaggeration to argue that Post independent India belied the hopes of poets and intellectuals as to a free and decolonised India in the real sense. Combined with this was the unrest caused in the international scene after World War II and the partition pain that prompted the poets to revise the long held values and start experimenting with the techniques. Giving up old traditional rhyme, gush of romantic similes, rhetoric and high sounding and sweeping imagery, they resorted to the concretization of thoughts and feelings expressed in a concrete style. In his introduction to Indian Poetry in English, Makarand Pranjape describes the literary scene and the new aesthetic of Post Independence poets:

Delayed by the idealism of nationalism and romanticism of Tagore and Naidu, this aesthetic found rapid acceptance in the disillusionment of post independence era. Instead of ushering in the promised golden age, independent India became a typical third world country, backward, corrupt and hypocritical. The blood bath of the partition was the worst blow to those who professed non violence.[3]

Ramanujan in his much acclaimed poem "A River", voices his concern over the deteriorating state of people in free India. The traditional symbol of river as the nourisher and preserver is turned upside down when its dried and billowed body in summer and during floods brings to mind the picture of malnourished and uncared humanity.

In Madurai,

city of temples and poets,

who sang of cities and temples,

every summer

a river dries to a trickle

in the sand,

The dismantling of the traditional ethos and symbols is coupled with a direct, matter of fact and unsentimental tone. Nissim Ezekiel presents almost a mortifying picture of Bombay where he studied, worked and lived by choice in a language which is direct and clipped. In 'Background Casually' he makes an ironic assessment of his lack of religious and regional identity although he seems to be making a commitment to stay 'where I am' 
displaying a kind of nationalism 'more sophisticated, ironic and critical' in Bruce King's words.[4] The poem "A Morning Walk" sees the poet wading through Bombay and he writes:

Barbaric city sick with slums,

Deprived of seasons, blessed with rains,

Its hawkers, beggars, iron-lunged,

Processions led by frantic drums

Kamala Das who wrote poems in a confessional style subverts the so called sacred institution of marriage and love that had become a mere stage for power games for the sexes in a spontaneous free verse

In "The Old Play House", she writes:

You planned to tame a swallow, to hold her

In the long summer of your love so that she would forget

Not the raw seasons alone, and the homes left behind, but

Also her nature, the urge to fly...

Also consider the poem "Dawn at Puri" by Jayanta Mahapatra

Endless crow noises,

A skull on the holy sands

Tilts its empty country towards hunger

The poem while valuing the concerns of the deeply religious people of India at the holy places like Puri in its surface text pulls down the very image through contrasting vignettes such as skull and holy sands, freedom and purity of white in the dress of the aged widows and the bondage of faith depicted through the "stare like those caught in the net".

Similar kind of particularity with more directness is observed in Arun Kolatkar's poem "Scratch"

What is god

And what is stone

The dividing line if exists

Is very thin

At Jejpuri

and every other stone

is god or his cousin

there is no crop other than god

around the year

and round the clock

out of bad earth

and the hard rock

Ranjit Hoskote in the poem "Two Women in Midsummer" depicts the plight of widows in India

Two women in midsummer

Sharing their loss

In traditional white

Walls, their bricks baked brown,

Relieved now and then

By pictures fading into cool green remembrances.

Idols in a corner, somewhat dusty;

The shrine is patient

Through forgetfulness and dried flowers.

Two women in midsummer

Adrift in a garden,

In rank weeds, unaccustomed perplexities.

Dark eyes gaze out blankly

Past the steam shivering over the coals,

The embers smoulder redly, unnoticed. 
The courtyard where they had sung

And splashed around in orange and yellow

Is starched and crisp and white.

Two women in midsummer

Stare across a many-pillared space,

A wordless space, a nameless space.

Even the crimson stains have gone.

In his collection of poems Zones of Assault, Hoskote deals with the specific areas of assault exposing the loss of lives of artist intellectuals which is a matter of concern for anybody. While mourning the assassination of the artist Safdar Hashmi, in 1989, he writes:

Smeared with permanent red,

Revelling in the offering,

They laughed the laugh of angel. [5]

\section{Conclusion}

Hence Indian poetry in English with its bent towards specificity and concretisation of style, subject and situation has become more relevant and readable in the context of the burgeoning violence, intolerance, inequality of power relations and the still prevalent divisive and discriminatory practices on the basis of region, gender, class, race and caste in the present times. In the poetry of specifics lies the potentiality of radicalism and change much required these days. The only thing one wonders if it could be more accessible for the common readers in terms of the language and diction as many new generation poets like Ranajit Hoskote and even Sudeep Sen at times resort to pedantry and jargon in their poems.

\section{References}

[1]. K.R. Srinivasa Iyengar. Indian Writing in English: The Seventies and After. ( New Delhi: Sterling, 1984)

[2]. Sri Aurobindo. The Future Poetry. (Pondicherry: Sri Aurobindo Ashram Publication,1997)17.

[3]. Paranjape, Makarand. Indian Poetry in English. (Madras: Macmillan, 1993) 19.

[4]. King, Bruce. Modern Indian Poetry in English.( London: OUP, 1987) 52.

[5]. Nair, Rama. ed.Trends and Techniques in Contemporary English Poetry. (New Delhi: Prestige, 2001$) 210$. 